\title{
PENERAPAN TEKNOLOGI INFORMASI DALAM PENINGKATAN EFEKTIVITAS, EFISIENSI DAN PRODUKTIVITAS PERUSAHAAN
}

\author{
Oleh : Henni Indrayani
}

\begin{abstract}
Abstraksi
Dalam menghadapi persaingan bisnis yang semakin kompetitif pada saat sekarang, perkembangan teknologi informasi mempunyai dampak yang sangat besar terhadap daya saing perusahaan. Agar perusahaan dapat bersaing, perusahaan secara terus-menerus harus mengikuti perkembangan dan kemajuan teknologi informasi. Salah satu keunggulan daya saing perusahaan menggunakan kriteria ekonomi dengan ukuran efektivitas, efisiensi dan produktivitas. Tujuan penerapan teknologi informasi bagi perusahaan adalah untuk mendapatkan rantai nilai dari teknologi informasi yang bermanfaat dalam semua aspek bisnis yang berorientasi kepada peningkatan efektivitas, efisiensi dan produktivitas karyawan dan perusahaan untuk mendapatkan margin yang telah ditargetkan dengan resiko dan biaya yang siminimal mungkin.
\end{abstract}

Kata kunci : teknologi informasi, efektivitas, efisiensi dan produktivitas.

\section{A. .Pendahuluan.}

Salah satu tantangan yang dihadapi pada era globalisasi dalam berbagai bidang kehidupan adalah teknologi informasi dan komunikasi. Teknologi Informasi merupakan bagian yang tidak dapat dipisahkan dari dunia usaha terutama dalam menghadapi persaingan bisnis yang semakin kompetitif. Kebutuhan akan teknologi informasi merupakan kebutuhan dasar perusahaan agar dapat bertahan dalam dunia usaha yang penuh persaingan. Teknologi informasi telah mendorong kemajuan dalam teknologi produk dan proses, serta terbentuknya masyarakat informasi.

Perubahan yang terjadi akibat globalisasi tersebut membawa dampak pada perubahan lingkungan bisnis yang meliputi perubahan teknologi, perubahan persepsi konsumen dan persaingan produk. Akibatnya perusahaan dituntut mampu meningkatkan kualitas produk, pelayanan, efisiensi, biaya produksi dan meningkatkan produktivitas perusahaan.
Akhirnya penguasaan teknologi informasi menjadi tuntutan yang harus dimiliki oleh perusahaan.

Disamping itu perkembangan teknologi informasi mempunyai dampak yang besar terhadap keunggulan daya saing perusahaan. Keunggulan daya saing perusahaan dapat dinilai berdasarkan kriteria ekonomi dengan menggunakan ukuran-ukuran seperti efektivitas, efisiensi dan produktivitas. Perkembangan teknologi informasi menciptakan produk dengan kapasitas besar, hemat energi dan dapat melakukan fungsi dan jenis pekerjaan yang semakin banyak serta dengan teknologi informasi dapat mengolah, menyimpan, menampilkan data dan informasi.

Untuk mencapai tujuan yang diinginkan perusahaan, setiap organisasi terbentuk dari tiga pilar utama, yaitu proses, sumberdaya manusia dan teknologi. Dalam mendesain serangkaian proses, ketiga elemen tersebut harus dipadukan sesuai dengan kebutuhan pasar (pelanggan). Perlu diperhatikan sumber 
daya manusia yang mengoperasikan proses tersebut, tehnologi juga digunakan untuk mendukung proses terutama tehnologi informasi. Tehnologi memainkan peran utama, bersama dengan proses dan sumber daya manusia. (Racmawati, 2004:28).

Dewasa ini sudah banyak ramalan yang mengatakan bahwa di masa depan akan terlihat "kantor tanpa kertas" (paperless office) berkat penggunaan mikro film, kaset, disket, CD Room dan sejenisnya. Juga dapat dipastikan, semakin meluasnya kegiatan komputerisasi dengan aplikasinya. Siapapun akan mengakui, bahwa teknologi informasi (TI) berkembang demikian pesatnya ( Siagian, 2002 : 209).

\section{Teknologi Informasi}

Istilah informasi diartikan beragam oleh para pakar. Definisi informasi secara internasional diartikan sebagai hasil dari pengolahan data yang secara prinsip memiliki nilai atau value yang lebih. Informasi merupakan (Hariandja, 2002:23) : (1) data yang diolah, (2) menjadi bentuk yang lebih berguna dan lebih berarti bagi yang menerima, (3) menggambarkan suatu kejadian-kejadian (event) dan kesatuan nyata, (4) digunakan untuk pengambilan keputusan.

Teknologi adalah pengembangan dan aplikasi dari alat, mesin, material dan proses yang menolong manusia menyelesaikan masalahnya. Selanjutnya Teknologi informasi adalah suatu teknologi yang digunakan untuk mengolah data, termasuk memproses, mendapatkan, menyusun, menyimpan, memanipulasi data dalam berbagai cara untuk menghasilkan informasi yang berkualitas, yaitu informasi yang relevan, akurat dan tepat waktu, yang digunakan untuk keperluan pribadi, bisnis, dan pemerintahan dan merupakan informasi yang strategis untuk pengambilan keputusan (http://computers-i ns.blogspot.com).

Sedangkan Martin mendefinisikan bahwa teknologi informasi tidak hanya terbatas pada teknologi komputer (perangkat keras dan perangkat lunak) yang digunakan untuk memproses dan menyimpan informasi melainkan juga mencakup teknologi komunikasi untuk mengirimkan informasi agar dapat di akses oleh semua orang (Kadir, 2005).

\section{Peranan Teknologi Informasi}

Pendorong utama globalisasi dalam berbagai bidang adalah kemajuan pesat dari teknologi informasi. Hanya berkat kemajuan teknologi ini maka prasarana yang memicu dan memungkinkan globalisasi disegala bidang seperti ekonomi, informasi dan sebagainya dapat dibangun. Kemajuan ini berikut penerapannya sangat pesat, sehingga produk yang dihasilkan datang silih berganti dengan cepat, seperti terlihat misalnya pada komputer yang hampir setiap tahun muncul dengan kemampuan yang semakin tinggi.

Saat ini teknologi informasi memainkan peranan di sebagian besar aspek bisnis perusahaan, dari pengembangan produk baru sampai dukungan penjualan dan jasa, dari penyediaan informasi pasar sampai data bagi analisis keputusan. Bagi sebuah perusahaan global, kemampuan untuk mengambil informasi dari berbagai sistem dan membuatnya dapat diakses luas oleh para manajer dan karyawan merupakan hal yang sangat penting (Dewi,2005:161).

Kemajuan teknologi informasi tidak hanya mendorong arus komunikasi global, tetapi juga memacu laju pertumbuhan informasi secara luar biasa. Komputer dan jaringan 
informasi mempercepat pertukaran pikiran dan informasi, melahirkan gagasan teoritis baru, mempersingkat dan mempermudah proses penelitian. Dengan kata lain kemajuan teknologi informasi mendorong pengembangan ilmu pengetahuan serta pengembangan informasi. Sementara itu, manusia yang terlibat dalam produksi informasi juga akan makin meningkat, menambah jumlah informasi.

Dalam dunia bisnis sekarang ini, maka perusahaan yang jauh lebih besar tidak selamanya memenangkan kompetisi terhadap perusahaan yang lebih kecil. Teknologi informasi mampu memberikan keunggulan kompetitif kepada perusahaan. Sebaliknya pengelolaan teknologi informasi yang tidak benar juga bisa membawa ke jurang kekalahan dalam persaingan bisnis. Bentuknya bisa seperti kehilangan pelanggan, kesalahan membuat produk (tidak sesuai dengan keinginan pasar), kehilangan karyawan handal, dan sebagainya.

Ketika penemuan teknologi informasi berkembang dalam skala masal, maka teknologi itu telah mengubah bentuk masyarakat, dari masyarakat dunia lokal menjadi masyarakat dunia global, sebuah dunia yang sangat transparan terhadap perkembangan informasi, transportasi serta teknologi yang begitu cepat dan besar mempengaruhi peradaban umat manusia, sehingga dunia dijuluki the big village yaitu sebuah desa yang besar di mana masyarakatnya saling kenal dan saling menyapa satu sama lainnya. Akses network dapat tiba dengan mudah dan cepat sehingga menjadi salah satu faktor dalam meningkatkan kinerja karyawan. Teknogi Informasi telah mengarahkan organisasi ke suatu bentuk yang semakin datar dan menciut (Bungin, 2006:159)

Contoh penggunaan email memberikan kemudahan bagi karyawan dalam melakukan komunikasi langsung dengan siapa saja tanpa harus melalui rantai birokrasi dan rantai komando yang panjang. Selain itu informasi yang dikirim dengan teknologi, informasi tersebut akan tiba di tempat yang di tuju dalam hitungan detik (Anatan, 2009:18).

\section{Efisiensi, Efektivitas dan Produktivitas}

Filosofi dan spirit tentang produktivitas sudah ada sejak awal peradaban manusia karena makna produktivitas ada keinginan (the will) dan upaya (effort) manusia untuk selalu meningkatkan kualitas kehidupan dan penghidupan di segala bidang. Menurut Encyclopedia Britania disebutkan bahwa produktivitas dalam ekonomi berarti rasio dari hasil yang dicapai dengan pengorbanan yang dikeluarkan untuk menghasilkan sesuatu.Sedangkan menurut formasi national productivity Board (NPB) Singapore, dikatakan bahwa produktivitas adalah sikap mental (attitude of mind) yang mempunyai semangat untuk melakukan peningkatan perbaikan. Dalam Laporan dewan produktivitas nasional tahun 1983 dikatakan bahwa produktivitas mengandung pengertian sikap mental yang selalu mempunyai pandangan "mutu kehidupan hari ini harus lebih baik dari kemarin dan hari esok lebih baik dari hari ini'(Sedarmayanti,2001:56-57).

Secara umum produktivitas mengandung pengertian perbandingan antara hasil yang dicapai (output) dengan keseluruhan sumber daya yang digunakan (input). Tingkat produktivitas yang dicapai merupakan suatu indikator terhadap efisiensi dan kemajuan ekonomi untuk ukuran suatu bangsa. Jadi dapat disimpulkan bahwa produktivitas adalah bagaimana menghasilkan atau meningkatkan hasil barang dan jasa setinggi mungkin dengan memanfaatkan sumber daya secara efisien. 
Dengan kata lain dapat dikatakan bahwa pengertian produktivitas memiliki dua dimensi yakni efektivitas dan efisiensi. Dimensi pertama berkaitan dengan pencapaian untuk kerja yang maksimal, dalam arti pencapaian target yang berkaitan dengan kualitas, kuantitas dan waktu. Sedangkan dimensi kedua berkaitan dengan upaya membandingkan masukan dengan realisasi penggunaannya atau bagaimana pekerjaan tersebut dilaksanakan (Sedarmayanti,2001:58).

Penjelasan tersebut mengutarakan produktivitas secara total atau secara keseluruhan artinya keluaran yang dihasilkan diperoleh dari keseluruhan masukan yang ada dalam organisasi. Masukan tersebut lazim dinamakan sebagai faktor produksi. Keluaran yang dihasilkan dicapai dari masukan yang melakukan proses kegiatan yang bentuknya dapat berupa produk nyata atau jasa. Masukan atau faktor produksi dapat berupa tenaga kerja, kapital, bahan, teknologi dan energi. Salah satu masukan seperti tenaga kerja, dapat menghasilkan keluaran yang dikenal dengan produktivitas individu, yang dapat juga disebut sebagai produktivitas parsial.

Efisensi merupakan suatu ukuran dalam membandingkan penggunaan masukan (input) yang direncanakan dengan penggunaan masukan yang sebenarnya terlaksana. Apabila masukan yang sebenarnya digunakan semakin besar peghematannya, maka tingkat efisiensi semakin tinggi, tetapi semakin kecil masukan yang dapat dihemat, sehingga semakin rendah tingkat efisiensi. Pengertian efisiensi disini lebih berorientasi kepada masukan sedangkan masalah keluaran (output) kurang menjadi perhatian utama.

Efektivitas merupakan suatu ukuran yang memberikan gambaran seberapa jauh target dapat tercapai. Pengertian efektivitas ini lebih berorientasi kepada keluaran sedangkan masalah penggunaan masukan kurang menjadi perhatian utama.

Kualitas merupakan suatu ukuran yang menyatakan seberapa jauh telah dipenuhi berbagai persyaratan, spesifikasi dan harapan. Konsep ini dapat berorientasi kepada masukan, keluaran atau keduanya. Disamping itu kualitas juga berkaitan dengan proses produksi yang akan berpengaruh pada kualitas hasil yang dicapai secara keseluruhan.

Secara skematis keterkaitan antara efisiensi, efektivitas, kualitas dan produktivitas dapat digambarkan pada gambar dibawah ini:

Efisiensi berorientasi pada masukan dan efektivitas berorientasi pada keluaran. Jadi dapat disimpulkan bahwa pengertian produktivitas adalah :

Efektivitas menghasilkan keluaran

Produktivitas $=$

Efisiensi penggunaan masukan

Efisiensi sebaiknya dianggap sebagai ukuran kualitas hasil pekerjaan di dalam suatu teknologi. Dengan perkataan lain efisiensi keorganisasian berhubungan dengan bagaimana sebaiknya sesuatu organisasi menerapkan teknologi tertentu. Sedangkan efektivitas keorganisasian dapat dianggap sebagai alat pengukur kualitas hubungan sebuah organisasi dengan lingkungannya (Winardi, 2003 :179).

Setiap organisasi mutlak perlu memegang prinsip efisiensi. Secara sederhana prinsip efisiensi pada dasarnya berarti menghindari segala bentuk pemborosan. Mengingat kenyataan bahwa kemampuan suatu organisasi mengadakan dan memiliki sarana dan prasarana kerja yang juga disebut sebagai sumber dana dan daya, yang diperlukannya guna menjalankan roda organisasi selalu 
terbatas, padahal tujuan yang ingin dicapai tidak terbatas, maka tidak pernah ada pembenaran untuk membiarkan pemborosan terjadi. Pengalaman dari berbagai organisasi menunjukkan dengan jelas bahwa banyak faktor penyebab terjadinya inefisiensi, misalnya pemborosan dapat timbul karena perilaku yang bersifat disfungsional dari para anggota organisasi dan karena ketidaksesuaian pengetahuan dan keterampilan para pelaku dalam menggunakan dan memanfaatkan sarana dan prasarana yang telah dimiliki itu.

Upaya peningkatan produktivitas kerja seyogyanya tidak dipandang hanya sebagai hal yang bersifat teknis. Segi-segi lain yang bahkan dapat berperan sebagai faktor penentu keberhasilan upaya tersebut antara lain sebagai berikut (Siagian, 2002:3-9)

\section{Tujuan Organisasi}

Siapapun akan mengakui bahwa suatu organisasi didirikan atau diciptakan oleh seorang atau sekelompok orang dengan maksud untuk menggunakannya sebagai wahana untuk mencapai tujuan tertentu. Para pakar umumnya sependapat bahwa tujuan akhir merupakan titik kulminasi ke arah mana organisasi akan dibawa dan berperan sebagai penuntun bagi organisasi dalam menyelenggarakan berbagai fungsi dan kegiatannya.

Pihak-pihak yang berkepentingan dalam kemajuan organisasi yang dapat berupa pertumbuhan, perkembangan, kemampuan bersaing, kemapanan, perolehan keuntungan yang lebih besar dan penguasaan pangsa pasar yang lebih besar ingin mengetahui bentuk-bentuk kemajuan yang diperoleh itu dari waktu ke waktu tanpa harus menunggu tercapainya tujuan akhir. Yang dimaksud dengan berbagai pihak yang berkepentingan (stakeholders) adalah mereka yang telah dan masih akan mempertaruhkan sesuatu demi kepentingan organisasi atau perusahaan seperti para pemodal, pemilik saham, kelompok manajemen, para karyawan dan bahkan juga para pemasok, agen, distributor dan pemerintah. Para menejer berusaha memenuhi keinginan pihakpihak yang berkepentingan itu dengan melakukan kajian mendalam yang menghasilkan dua jenis tujuan antara yaitu tujuan jangka menengah dan tujuan jangka pendek. Ciri-cirinya antara lain :

(a) sifatnya tidak lagi idelistik tetapi pragmatis

(b) batas waktu pencapaiannya ditentukan, misalnya sepuluh tahun, lima tahun atau setahun

(c) hasil-hasil yang diharapkan dicapai dinyatakan secara konkret

(d) hasil dimaksud tergambar secara kuantitatif

yang mutlak harus terjadi ialah bahwa semua menerima tujuan tersebut sebagai sesuatu yang wajar, layak, dan pantas untuk dicapai. Dengan demikian, para pelaku akan bersedia terlibat dalam membuat komitmen yang lebih besar kearah keberhasilan organisasi termasuk di dalamnya peningkatan produktivitas kerja.

2. Perumusan Visi dan Misi

Dalam rangka mencapai tujuan akhir, manajemen menyatakan arah yang akan ditempuh oleh organisasi sehingga terwujud suatu keadaan yang diinginkan pada suatu waktu tertentu dimasa depan. Dengan kata lain, manajemen perlu menyatakan pandangannya secara eksplisit tentang bentuk masa depan organisasi yang dikehendakinya. Itulah yang dimaksud sebagai visi. Atas dasar rumusan visi, misi dapat ditentukan. Misi adalah sesuatu yang harus diemban oleh semua komponen organisasi berupa kegiatan pokok yang kesemuanya dilakukan dalam rangka pencapaian 
tujuan yang telah ditetapkan sebelumnya. Dengan demikian, jelaslah bahwa visi dan misi harus mempunyai keeterkaitan kuat dan relevansi yang tinggi dengan tujuan yang ingin dicapai.

3. Penentuan Strategi Organisasi

Strategi merupakan kiat yang diterapkan biasanya oleh manajemen puncak untuk memenangkan peperangan yang melibatkan organisasi. Dalam dunia bisnis lumrah untuk mengatakan bahwa strategi merupakan pernyataan umum oleh manajemen puncak tentang kegiatan bisnis apa yang dilakukan organisasi sekarang dan dalam bidang bisnis apa organisasi ingin bergerak di masa depan. Manajemen puncak harus mengetahui betul faktor-faktor kekuatan apa yang dimiliki oleh organisasi, kelemahan apa yang mungkin terdapat didalamnya, peluang apa yang mungkin timbul dan bagaimana cara memanfaatkannya, serta ancaman apa yang mungkin timbul dan bagaimana cara memanfaatkannya, serta ancaman apa yang paling efektif untuk menghadapinya. Sebaliknya perlu diketahui kekuatan dan kelemahan lawan sehingga dapat ditentukan kiat yang tepat sehingga lawan tidak memiliki kemampuan untuk memanfaatkan peluang dan bahkan apabila mungkin menghilangkan peluang tersebut sehingga tidak memiliki keandalan dalam menghadapi ancaman yang dihadapinya.

4. Pemanfaatan Teknologi dan Produktivitas Kerja

Tidak dapat disangkal lagi bahwa berbagai terobosan yang terjadi dibidang teknologi dapat memberikan sumbangan yang besar kepada peningkatan produktivitas kerja suatu organisasi. Apabila dipilih dengan tepat, teknologi dapat diterapkan pada semua jenis kegiatan dalam organisasi. Tidak dapat dipungkiri bahwa teknologi informasi berkembang dengan pesat dengan aplikasinya yang beraneka ragam, antara lain karena perkembangan yang tidak kalah pesatnya dibidang perangkat lunak. Berbagai terobosan dibidang ini telah berhasil menciptakan komputer yang semakin canggih, dalam arti ukurannya semakin kecil, kemampuannya semakin tinggi, penggunaannya semakin mudah dan harganya semakin murah. Implikasinya pun semakin banyak, seperti dalam proses pengambilan keputusan yang secara tradisional dalam banyak organisasi tadinya yang bersifat sentralistik, akan tetapi karena akses kepada perangkat keras dan perangkat lunak semakin luas dan makin mudah, maka berubah menjadi desentralistik. Demikian prevalennya teknologi informasi dewasa ini sehingga sangat sukar untuk membayangkan adanya aspek kehidupan dan kegiatan organisasional yang tidak disentuh oleh komputerisasi.

\section{Penerapan Teknologi Informasi dalam Peningkatkan Efektivitas, Efisiensi dan Produktivitas Perusahaan}

Teknologi informasi terdiri dari berbagai jenis teknologi. Teknologi yang digunakan pada sistem informasi teknologi adalah teknologi komputer, teknologi komunikasi, dan teknologi apapun yang memberikan nilai tambah bagi organisasi (Jogiyanto,2009:7).

Beberapa alasan penggunaan teknologi informasi, antara lain :

1. Secara signifikan meningkatkan pilihanpilihan yang tersedia bagi perusahaan dan memegang peranan penting dalam implementasi yang efektif terhadap kinerja perusahaan.

2. Mempengaruhi proses pengembangan strategi pemasaran karena teknologi informasi memberikan lebih banyak 
informasi ke manajer melalui pemakaian sistem pengambilan keputusan (Decision Support System atau DSS).

3. Teknologi informasi memiliki kemampuan untuk mengintegrasikan berbagai bagian yang berbeda dalam organisasi dan menyediakan banyak informasi ke manajer. Sebagai contoh, Sistem Informasi Eksekutif (Executive Information System Atau EIS) mempengaruhi aliran informasi secara vertikal dalam perusahaan. Pihak manajemen akan memiliki akses informasi yang lebih besar dan mengurangi ketergantungan sumber informasi terhadap manajer menengah. Jaringan telekomunikasi memungkinkan informasi mengalir dengan mudah dan cepat di antara departemen dan devisi yang berbeda.

4. Teknologi informasi juga mempengaruhi antara organisasi dengan lingkungan seperti pelanggan dan pemasok. Sistem antara organisasi yang dilengkapi dengan pertukaran data menciptakan hubungan yang lebih dekat antara organisasi dan pemasok, memfasilitasi manajemen persediaan yang lebih efisien dan memungkinkan pendekatan tepat waktu dalam pemesanan kembali.

5. Membantu dalam menghasilkan inovasi produk. Teknologi Informasi dapat membantu dalam mendesain produk hingga proses produksi menjadi lebih efektif dan efisien.

Tujuan penerapan teknologi bagi perusahaan adalah untuk mendapatkan rantai nilai dari teknologi informasi yang bermanfaat dalam semua aspek bisnis yang berorientasi kepada peningkatan efektivitas, efisiensi dan produktivitas karyawan dan perusahaan untuk mendapatkan margin yang telah ditargetkan dengan resiko dan biaya yang siminimal mungkin.

Berdasarkan hasil peneltian Yeung dan Brockbank (1994) terhadap 160 eksekutif perusahaan besar California menunjukkan terdapat tiga faktor utama yang mendorong dilakukan reengineering yakni: pengurangan biaya, peningkatan mutu pelayanan yang lebih baik dan perubahan budaya perusahaan. Hasil penelitian tersebut menunjukkan bahwa faktor pengurangan biaya merupakan urutan pertama yakni $78 \%$ dari jawaban responden, urutan kedua untuk meningkatkan kualitas pelayanan $(76 \%)$ sedangkan urutan ke tiga (70\%) merubah budaya perusahaan yang bertujuan mengurangi birokrasi dan memberdayakan perusahaan. Dengan reengineering SDM diharapkan setelah layanan sdm yang penting dan rutin terarah serta terstandarisasi dengan menggunakan teknologi informasi, maka fungsi-fungsi sdm dapat dibebaskan dari standar dan arah tersebut guna lebih memfokuskan pada aktivitas-aktivitas sdm yang bernilai tambah tinggi (Rachmawati, 2004:28-29).

Penggunaan teknologi informasi dalam sebuah organisasi sangatlah penting, untuk menerapkan teknologi informasi harus dilihat karakteristik organisasi tersebut. Apakah dengan teknologi informasi mampu meningkatkan efisiensi sebuah perusahaan, sehingga dalam penerapan teknologi informasi dibutuhkan orang yang handal, agar perusahaan dapat berjalan dengan baik. Peran teknologi informasi bagi sebuah perusahaan dapat dilihat dengan menggunakan kategori yang diperkenalkan oleh G.R. Terry, ada 5 peranan mendasar teknologi informasi di sebuah perusahaan, yaitu : (http://computers-inc.blogspot.com).

1. Fungsi operasional, akan membuat struktur organisasi menjadi lebih ramping telah diambil alih fungsinya oleh teknologi informasi. Karena sifat penggunaannya yang menyebar di seluruh fungsi organisasi, unit terkait dengan manajemen teknologi informasi akan menjalankan fungsinya sebagai supporting agency 
dimana teknologi informasi dianggap firm infrastructure.

2. Fungsi Monitoring dan kontrol mengandung arti bahwa keberadaan teknologi informasi akan menjadi bagian yang tidak terpisahkan dengan aktivitas di level manajerial dalam setiap fungsi manajer, sehingga struktur organisasi unit terkait dengannya harus dapat memiliki span of control atau peer relationship yang memungkinkan terjadinya interaksi efektif dengan para manajer di perusahaan terkait.

3. Fungsi Planning and Decision mengangkat teknologi informasi ke tataran peran yang lebih strategis lagi karena keberadaannya sebagai enabler dari rencana bisnis perusahaan dan merupakan sebuah knowledge generator bagi para pemimpin perusahaan yang dihadapkan pada realitas untuk mengambil sejumlah keputusan penting sehari-harinya. Tidak jarang perusahaan yang pada akhirnya memilih menempatkan unit teknologi informasi sebagai bagian dari fungsi perencanaan dan/ atau pengembangan korporat karena fungsi strategis tersebut di atas.

4. Fungsi Communication secara prinsip termasuk ke dalam firm infrastructure dalam era organisasi modern dimana teknologi informasi ditempatkan posisinya sebagai sarana atau media individu perusahaan dalam berkomunikasi, berkolaborasi, berkooperasi, dan berinteraksi.

5. Fungsi Interoganisational merupakan sebuah peranan yang cukup unik karena dipicu oleh semangat globalisasi yang memaksa perusahaan untuk melakukan kolaborasi atau menjalin kemitraan dengan sejumlah perusahaan lain. Konsep kemitraan strategis atau partnerships berbasis teknologi informasi seperti pada implementasi Supply Chain Management atau Enterprise Resource Planning membuat perusahaan melakukan sejumlah terobosan penting dalam mendesain struktur organisasi unit teknologi informasinya.

Tujuan usaha yang dinyatakan oleh Porter, yaitu efektivitas operasional dan strategi positioning yang lebih lanjut dihubungkan dengan penerapan teknologi tnformasi, Jika perusahaan berfokus pada strategi operasi, maka dengan penerapan teknologi informasi, perusahaan bisa meningkatkan efisiensi dengan : (Talon : 1999).

1. mengurangi biaya operasi

2. meningkatkan kualitas produk

3. mempercepat produksi

4. meningkatkan efektivitas perusahaan secara umum

Oleh karena itu, dalam usaha meningkatkan efisiensi, efektivitas, dan produktivitas perusahaan, penerapan dibidang teknologi informasi menuntut para manajer untuk memikirkan dan mengambil langkah-langkah untuk dapat memanfaatkan sumber daya manusia dengan memberikan kepada karyawan keterampilan baru melalui pelatihan.

\section{Kesimpulan}

1. Peranan teknologi informasi dalam perusahaan baik perusahaan besar, sedang maupun kecil membutuhkan sistem informasi yang dapat mengintegrasikan informasi sehingga dapat mendukung produktivitas perusahaan.

2. Penerapan teknologi Informasi dalam organisasi harus didukung oleh sumberdaya manusia yang handal, oleh 
karena itu dalam usaha meningkatkan efisiensi, efektivitas dan produktivitas perusahaan dapat dilakukan dengan memberikan keterampilan melalui pelatihan kepada karyawan.

3. Diperlukan penguasaan teknologi informasi untuk diaplikasikan pada seluruh proses dan sistem produksi dan peningkatan keandalan para manajer sebagai pengambilan keputusan.

\section{Daftar Pustaka}

Bungin, Burhan (2008), Riset Komunikasi, Penerbit: Kencana Pranada, Media Group, Jakarta.

Dewi, Ike Janita (2005), Rethinking Information Tecnology Management: Integrasi Teknologi Informasi dengan Strategi, Penerbit: Amara Books, Yogyakarta.

Ellitan, Lena dan Lina Anatan (2009), Sistem Informasi manajemen "Konsep Dan Praktis", Penerbit: Alfabeta, Jakarta.

Hariandja, Marihat Tua Efendi (2002), Sumber Daya Manusia, Penerbit: PT Grasindo, Jakarta.

http://computers-ins.blogspot.com. Diakses 25 September 2012.

Jogiyanto,H.M (2009), Sistem Teknologi Informasi, Penerbit: BPFE, Yogyakarta.
Kadir, Abdul, dan Tera Ch Wahyuni (2005), Pengenalan Teknologi, Penerbit Andi, Jakarta

Racmawati, Eka Nuraini (2004), Paradigma Baru Manajemen Sumber Daya Manusia Sebagai Basis Meraih Keunggulan Kompetitif, Penerbit: Ekonisia, UII, Yogyakarta.

Sedarmayanti (2001), Sumber Daya Manusia dan Produktivitas Kerja, Penerbit: CV. Mandar Maju, Bandung

Siagian, P Sondang (2002), Kiat Meningkatkan Produktivitas Kerja, Penerbit: Rineka Cipta, Jakarta.

Talon Paul P, K.L.Kramer and V.Gurbaxni (2000), Executif Persenton Of The Business Value of Information Technology:A Prosess-oriented Approach.

Winardi J (2003), Teori Organisasi dan Pengorganisasian, PT. Raja Grafindo Persada, Jakarta.

Jakarta, Kencana Prenada Media Group. 